\title{
Methodiek werkveldonderzoek Hogeschool INHOLLAND
}

\author{
Citation for published version (APA):
}

Ramaekers, G. W. M., Allen, J. P., Heijke, J. A. M., van Loo, J. B., \& van der Velden, R. K. W. (2004). Methodiek werkveldonderzoek Hogeschool INHOLLAND. Researchcentrum voor Onderwijs en Arbeidsmarkt, Faculteit der Economische Wetenschappen. ROA Working Papers No. 1 https://doi.org/10.26481/umarow.2004001

Document status and date:

Published: 01/01/2004

DOI:

10.26481/umarow.2004001

Document Version:

Publisher's PDF, also known as Version of record

\section{Please check the document version of this publication:}

- A submitted manuscript is the version of the article upon submission and before peer-review. There can be important differences between the submitted version and the official published version of record.

People interested in the research are advised to contact the author for the final version of the publication, or visit the DOI to the publisher's website.

- The final author version and the galley proof are versions of the publication after peer review.

- The final published version features the final layout of the paper including the volume, issue and page numbers.

Link to publication

\footnotetext{
General rights rights.

- You may freely distribute the URL identifying the publication in the public portal. please follow below link for the End User Agreement:

www.umlib.nl/taverne-license

Take down policy

If you believe that this document breaches copyright please contact us at:

repository@maastrichtuniversity.nl

providing details and we will investigate your claim.
}

Copyright and moral rights for the publications made accessible in the public portal are retained by the authors and/or other copyright owners and it is a condition of accessing publications that users recognise and abide by the legal requirements associated with these

- Users may download and print one copy of any publication from the public portal for the purpose of private study or research.

- You may not further distribute the material or use it for any profit-making activity or commercial gain

If the publication is distributed under the terms of Article $25 \mathrm{fa}$ of the Dutch Copyright Act, indicated by the "Taverne" license above, 


\title{
Methodiek Werkveldonderzoek Hogeschool INHOLLAND
}

\author{
ROA-W-2004/1 \\ Ger Ramaekers, Jim Allen, Hans Heijke, Jasper van Loo, Rolf van der Velden
}

Researchcentrum voor Onderwijs en Arbeidsmarkt

Faculteit der Economische Wetenschappen en Bedrijfskunde Universiteit Maastricht

Maastricht, februari 2004 
ISBN 90-5321-386-4

Sec04.015.doc 


\section{Inhoud}

Pagina

Voorwoord

1 Inleiding 1

2 Verschillende typen werkveldonderzoek 2

3 Inhoud en gebruiksdoelen van het werkveldonderzoek 5

$\begin{array}{ll}3.1 \text { Een onderzoek in drie lagen } & 5\end{array}$

$\begin{array}{lr}3.2 \text { Werkgeversvragenlijst } & 7\end{array}$

3.3 Gebruiksdoelen 10

4 Opzet van het pilot-project 11

4.1 Onderzoekspopulatie en wijze van dataverzameling 11

4.2 Verslag van de dataverzameling $\quad 12$

4.3 Respons en representativiteit $\quad 15$

5 Conclusies 17

$\begin{array}{ll}\text { Literatuur } & 18\end{array}$

Appendix: Vragenlijst Werkveldonderzoek Hogeschool INHOLLAND 



\section{Voorwoord}

In mei 2003 heeft Hogeschool INHOLLAND het Researchcentrum voor Onderwijs en Arbeidsmarkt (ROA) van de Universiteit Maastricht opdracht verleend een instrument te ontwikkelen waarmee de mening van het werkveld over de kwaliteit van haar opleidingen in kaart kan worden gebracht. Het instrument is getest in een pilot-project, dat heeft plaatsgevonden in het kader van de accreditatie van een elftal opleidingen van Hogeschool INHOLLAND.

Het ROA had bij het uitvoeren van het pilot-project de leiding, en was verantwoordelijk voor de instrumentontwikkeling, de kwaliteitsbewaking en het onderzoeksverslag. In het project werkte het ROA nauw samen met DESAN Research Solutions te Amsterdam. DESAN was verantwoordelijk voor de gegevensverzameling en de verwerking hiervan.

Vanuit de Hogeschool INHOLLAND is het project begeleid door Elisabeth Köllen. Het onderzoeksinstrument is binnen het ROA ontwikkeld door Jim Allen, Jasper van Loo, Hans Heijke, Ger Ramaekers en Rolf van der Velden. Voorts hebben Paul van der Kolk en Esther Soudant van het ROA ondersteuning verleend bij de data-technische aspecten van het project. De projectleiding was in handen van Ger Ramaekers. Monique van Alphen coördineerde de werkzaamheden van DESAN Research Solutions voor het pilot-project.

Een woord van dank geldt de oud-studenten van de hogeschool in Alkmaar, Diemen, Haarlem, Rotterdam en Delft, thans deel uitmakend van de Hogeschool INHOLLAND, die aan het onderzoek hun medewerking hebben verleend, en zeker niet in de laatste plaats de werkgevers van deze oud-studenten. 



\section{Inleiding}

Van hoger opgeleiden wordt een belangrijke bijdrage verwacht aan de kenniseconomie. Deze onderscheidt zich van de bijdrage van lager opgeleiden. In het algemeen laten zich vier economische effecten van kennis onderscheiden: het researcheffect, het diffusie-effect, het allocatie-effect en het arbeidseffect (Cörvers, 1999). Het researcheffect verwijst naar de effecten van innovaties op de economische groei (groei van de productiviteit van productiefactoren). Het diffusie-effect verwijst naar de effecten van de introductie en verspreiding van, bijvoorbeeld door R\&D, ontwikkelde nieuwe technieken. Het allocatieeffect wijst op het efficiënter en effectiever omgaan met de productiefactoren binnen de organisatie. Het arbeidseffect, tenslotte, duidt op het in het algemeen hogere productieve vermogen van hoger opgeleiden. Hoger opgeleiden zullen relatief hoog scoren ten aanzien van al deze effecten, maar zij zullen in het bijzonder hoog scoren op het researcheffect. Hun inzet is dus van cruciaal belang voor het proces van technologische en organisatorische vernieuwing. Daarnaast spelen zij een belangrijke rol bij de verspreiding van innovaties binnen organisaties en het efficiënt en effectief organiseren van het productieproces. Tenslotte zullen zij hun functie relatief efficiënt uitoefenen.

De $\mathrm{HBO}$ (en WO)-Monitor geeft maar een partieel beeld van de economische betekenis van hoger opgeleiden. De monitor geeft een actueel beeld van de positie van pas afgestudeerden op de arbeidsmarkt, inclusief de aard van de organisaties waar zij werkzaam zijn en de functie die zij daar uitoefenen. Ook geeft de monitor een beeld van hoe zij in hun baan functioneren. Dit echter uitsluitend gezien door de bril van de afgestudeerden zelf. Voor een goed beeld van de betekenis van de afgestudeerden voor de kenniseconomie is echter ook de visie van de werkgevers hierop van belang. De monitor geeft geen informatie over hoe de hoger opgeleiden functioneren, specifiek in het kader van de uitdagingen en onzekerheden waarvoor organisaties gesteld zijn. Er zou moeten worden onderzocht welke rol werkgevers weggelegd zien voor hoger opgeleiden in het kader van:

- De ontwikkelingen op hun markten van inputs en outputs en hun concurrentiepositie op deze markten.

- De wijze waarop zij het productieproces hebben georganiseerd door het inzetten van arbeid en productietechnologie - gegeven hun relaties met klanten en toeleveranciers, de overheid en externe bronnen van informatie en kennis.

- Het belang van het doorvoeren van technologische en organisatorische vernieuwingen voor het voortbestaan van de organisatie.

Kortom, er zou meer inzicht moeten zijn in hoe hoger opgeleiden passen in het ondernemingsbeleid dat is gericht op het gebruik van kennis voor het tegemoet treden van de onzekerheden en uitdagingen die zijn verbonden aan ontwikkelingen op markten en in technologie en organisatie.

In dit werkdocument wordt de opzet en uitvoering geschetst van bovenbedoeld bedrijvenonderzoek dat is uitgevoerd als aanvulling op de HBO-Monitor in een pilot-project bij de Hogeschool INHOLLAND. Het werkdocument bevat geen inhoudelijke analyses. Deze worden elders gepubliceerd. Zo is ten behoeve van de zelfevaluatie van Hogeschool 
INHOLLAND een rapport gemaakt over de onderzoeksresultaten van deze pilot onder werkgevers. Het onderzoek is verricht door het Researchcentrum voor Onderwijs en Arbeidsmarkt (ROA) in samenwerking met DESAN Research Solutions. In dit pilotonderzoek zijn 938 oud-studenten van een elftal opleidingen van Hogeschool INHOLLAND benaderd, met het verzoek om een werkgeversvragenlijst door te geven aan hun directe leidinggevende. Uiteindelijk zijn 88 ingevulde werkgeversvragenlijsten terug ontvangen, ofwel een respons van 9,4\%. Verschillende factoren blijken een rol te spelen bij deze teleurstellende respons. Geen interesse is slechts één van die factoren. Een verouderd adres een andere factor. Daarnaast blijkt dat de respons afneemt, naarmate men langer is afgestudeerd. Deels heeft dit te maken met verouderde adressen, maar wellicht ook met een afnemende binding met de opleiding. In paragraaf 4.3 worden de ervaringen beschreven die zijn opgedaan in een vergelijkbaar onderzoek onder werkgevers van oud-studenten van de Universiteit Maastricht. Ook in dit onderzoek was de respons teleurstellend laag.

De opzet van dit werkdocument is als volgt. Allereerst wordt in hoofdstuk 2 ingegaan op de voor- en nadelen van verschillende typen onderzoek onder werkgevers, en wordt de keuze beargumenteerd om werkgevers via afgestudeerden te benaderen. Vervolgens wordt in hoofdstuk 3 een uiteenzetting gegeven van de inhoud en gebruiksdoelen van het ontwikkelde onderzoeksinstrument. Hoofdstuk 4 schetst een beeld van de onderzoekspopulatie, dataverzameling en representativiteit van de respons in het pilot-project bij de Hogeschool INHOLLAND. Tot slot worden in hoofdstuk 5 de belangrijkste bevindingen over de gevolgde onderzoeksaanpak samengevat.

\section{Verschillende typen werkveldonderzoek}

In onderzoeken onder werkgevers kunnen verschillende typen worden onderscheiden (de term werkveldonderzoek is wellicht een betere benaming omdat de werkgever zelf niet altijd centraal hoeft te staan). Een hoofdonderscheid is tussen onderzoeken waarin de organisatie de analyse-eenheid vormt, en onderzoeken waarin de werkplek de analyse-eenheid vormt.

\section{De organisatie als analyse-eenheid}

Onderzoeken waarin de organisatie centraal staat als analyse-eenheid zijn doorgaans gericht op het algemeen strategisch beleid van een organisatie, zoals het beleid ten aanzien van selectie van personeel, HRM, scholing en loopbaanontwikkeling. Dit type onderzoek gaat er van uit dat dergelijke informatie equivalent is voor alle functies in de organisatie of voor alle hoger opgeleide medewerkers. Vandaar dat in dit soort onderzoeken doorgaans niet wordt gedifferentieerd tussen verschillende functies of verschillende opleidingen.

In dit type onderzoek manifesteren zich doorgaans twee vragen. De eerste vraag is of grote organisaties zwaarder zouden moeten wegen in de analyse dan kleine organisaties. Immers, het beleid van grote organisaties heeft verder reikende repercussies voor de beroepsbevolking dan het beleid van kleine organisaties. Dit vraagstuk wordt doorgaans onvoldoende verdisconteerd in onderzoek. Meestal wordt gewerkt met een gestratificeerde steekproef- 
opzet, waarbij grote organisaties een grotere kans hebben om in de steekproef te vallen, maar dit is niet hetzelfde als het wegen van de data naar organisatiegrootte. Een andere vraag is of nevenvestigingen van een zelfde organisatie als verschillende eenheden moeten worden gerekend (hetgeen zou moeten bij een sterk gedecentraliseerd personeelsbeleid). In het werkveldonderzoek voor Hogeschool INHOLLAND is echter niet gekozen voor de organisatie als analyse-eenheid, maar voor de functie als analyse-eenheid.

\section{De functie als analyse-eenheid}

Onderzoeken waarin de functie de analyse-eenheid vormt, zijn doorgaans gericht op zaken als functie-eisen, verwachte ontwikkelingen binnen functies, evaluatie van degenen die de functies vervullen, etc. Het gaat hierbij om informatie die specifiek is voor verschillende soorten functies en verschillende opleidingen. Een typisch steekproefontwerp is dat organisaties worden geselecteerd op basis van vacature-advertenties. De vragen richten zich dan op deze vacatures, de functie-eisen, en degenen die geselecteerd zijn voor de functies. Een ander steekproefontwerp is dat organisaties worden geselecteerd die representatief zijn voor het werkveld van een bepaald beroep. De moeilijkheid hierbij is om het steekproefontwerp te definiëren. $\mathrm{Er}$ is immers geen één-op-één relatie tussen organisaties en beroepen: organisaties herbergen doorgaans meerdere beroepen, en beroepen zijn doorgaans verspreid over soms zeer verschillende soorten organisaties. De vraag rijst hoe een goed steekproefontwerp moet worden vastgesteld (bijvoorbeeld, welke organisaties moeten worden geselecteerd voor de functies van bijvoorbeeld ingenieurs, en welke organisaties voor ander soort functies; hoe moet met het vraagstuk worden omgegaan dat voor sommige specifieke functies geen typische organisatie bestaat, bijvoorbeeld in het geval van een secretaresse).

Een mogelijkheid voor onderzoek waarin de functie de analyse-eenheid vormt, is om werkgevers via afgestudeerden te benaderen. Hierdoor ontstaat automatisch een representatief steekproefbestand van werkgevers van afgestudeerden. Daarbij komt dat de eenheid van analyse duidelijk is, en er geen misverstand mogelijk is over de soort functie waarover de mening van de werkgever wordt gevraagd, namelijk de functie van de afgestudeerde. Een complicerende factor bij dit steekproefontwerp is evenwel de mogelijke negatieve 'selection bias': afgestudeerden die een conflict met hun baas hebben, zullen minder geneigd zijn om de vragenlijst aan hun werkgever door te geven. Een verdere complicatie is dat een benadering van werkgevers via afgestudeerden doorgaans vrij kostbaar is, tenzij een onderzoek onder de afgestudeerden zelf toch al gepland was.

Voor- en nadelen om werkgevers te benaderen via de afgestudeerdenenquête

Belangrijke voordelen zijn:

- Kostenbesparing: vergeleken met een separaat werkgeversonderzoek zijn de additionele kosten van een onderzoek onder de werkgevers van de afgestudeerden relatief laag.

- Evenwichtig steekproefontwerp: deze benadering genereert automatisch een representatieve steekproef van relevante werkgevers. 
- Mogelijkheid om beide soorten informatie aan elkaar te koppelen: informatie van de afgestudeerde kan direct worden gekoppeld met de informatie van zijn werkgever over selectiecriteria en functie-eisen.

- Mogelijkheid om de informatie van de werkgevers naar opleiding te aggregeren: omdat de functies van de afgestudeerden de analyse-eenheid vormen, kan de informatie van de werkgevers niet alleen worden geaggregeerd naar functie of branche (zoals gewoonlijk gebeurt in werkgeversonderzoeken), maar ook worden geaggregeerd naar opleiding. Dit maakt directe feedback mogelijk naar de onderwijsinstellingen.

- Hogere respons onder werkgevers: de werkgever zal zich meer betrokken voelen, en de werkgeversvragenlijst kan aanmerkelijk korter zijn omdat veel informatie reeds is verzameld middels de afgestudeerdenvragenlijst.

Nadelen zijn:

- Het grootste nadeel vormt de reeds genoemde negatieve 'selection bias', waar niet te licht over mag worden gedacht. Deze selectiviteit kan worden teruggebracht door de afgestudeerde volledig inzicht te verschaffen in de inhoud van de werkgeversvragenlijst. Essentieel hierbij is dat de werkgeversvragen niet betrekking hebben op de desbetreffende afgestudeerde, maar op afgestudeerden van dit opleidingstype in het algemeen.

- Een gecombineerde afgestudeerden-werkgevers enquête kan ook een negatief effect hebben op de respons van de afgestudeerden zelf (er wordt immers veel van hen gevraagd).

- Een directe link tussen de twee onderzoeken kan strijdig zijn met de vertrouwelijkheid van de informatie, en kan de relatie tussen afgestudeerde en werkgever beïnvloeden. Vragen over het oordeel van de werkgever over de afgestudeerde dienen te worden vermeden.

\section{Pilot projecten}

Gezien de bovengenoemde voordelen is gekozen voor een gecombineerde afgestudeerdenwerkgevers benadering. De respondent hierbij is de directe leidinggevende van de afgestudeerde. Vergeleken met andere respondenten (bijvoorbeeld de personeelsfunctionaris) heeft dit het voordeel van duidelijkheid. Een mogelijk nadeel is dat sommige zaken betreffende het algemeen beleid van de organisatie wellicht niet bekend zijn bij de directe leidinggevende. ${ }^{2}$

Om ervaring op te doen met dergelijke gecombineerde afgestudeerden-werkgevers enquêtes, heeft het ROA in 2003 twee pilot onderzoeken verricht. Het eerste pilot project is een onderzoek onder werkgevers van oud-studenten van Hogeschool INHOLLAND (afstudeercohort 1999/2000 en 2000/2001). In dit pilot onderzoek zijn de werkgevers via de oud-studenten benaderd, maar zijn de oud-studenten zelf niet geënquêteerd. Over dit pilot project wordt hier uitvoerig gerapporteerd. Het andere pilot onderzoek heeft betrekking op

1. Echter, de mogelijke 'selection bias' in andere onderzoekdesigns mag ook niet worden onderschat.

2. Dit probleem kan zich ook voordoen in andere typen werkgeversonderzoek. Het voordeel is echter dat exact bekend is wie de respondent is, en welk soort vragen al dan niet kunnen worden gesteld. 
werkgevers van oud-studenten (afstudeercohort 1996/1997, dus zo'n 6 jaar na afstuderen) van de Faculteit der Economische Wetenschappen en Bedrijfskunde (FdEWB) van de Universiteit Maastricht. Dit gecombineerde afgestudeerden-werkgevers onderzoek betreft een enquête onder zowel de oud-studenten als hun werkgevers. De resultaten van dit pilot project worden hier slechts gebruikt als vergelijkingsmateriaal met betrekking tot de responsproblematiek.

In beide pilot projecten kan mogelijke 'selection bias' worden achterhaald. Immers, door de groep oud-studenten van wie de werkgever heeft gerespondeerd te vergelijken met de groep oud-studenten van wie de werkgever niet heeft gerespondeerd, kan worden nagegaan of beide groepen in relevante baankenmerken verschillen (bijvoorbeeld ten aanzien van de aansluiting opleiding-werk). Het pilot project van de Universiteit Maastricht biedt daarnaast de mogelijkheid om de gevolgen van een gecombineerde afgestudeerden-werkgevers benadering voor de hoogte van de respons bij de afgestudeerdenenquête zelf te achterhalen. Dit, omdat van alle oud-studenten van de Universiteit Maastricht alleen de oudstudenten van de FdEWB zijn gevraagd om aan het werkgeversonderzoek mee te werken.

\section{Inhoud en gebruiksdoelen van het werkveldonderzoek}

\subsection{Een onderzoek in drie lagen}

In het bovenstaande werd de rol van hoger opgeleiden in organisaties slechts in algemene zin aangeduid. Het hbo en de specifieke opleidingen hierbinnen beogen binnen deze algemene rol een eigen bijzondere positie in te nemen. Vergeleken met het universitaire onderwijs, zijn hbo-opleidingen meer gericht op de toepassing van bestaande kennis binnen bepaalde beroepsvelden. Dit betekent echter niet dat hbo'ers niet betrokken zijn bij het proces van technologische innovatie. Vaak treft men hbo'ers aan als specifieke professionals of als kaderfunctionarissen in organisaties (incl. overheden/instellingen) die, met name later in de loopbaan, leidinggevende rollen vervullen en daarin hun specifieke veldkennis combineren met al dan niet in de opleiding opgedane organisatorische en financiële vaardigheden en kennis. Omdat de focus van een specifieke opleiding kan verschillen ten aanzien van deze algemene positionering en ten aanzien van de inhoud van het specifieke beroepsveld, moet het bedrijvenonderzoek ook op het niveau van concrete opleidingen informatief zijn.

Dit zou resulteren in een bedrijvenonderzoek dat in drie lagen is opgebouwd.

- De eerste, binnenste, laag betreft de specifieke bijdrage van de opleiding van de desbetreffende afgestudeerde ten aanzien van de vervulling van de rollen voor hoger opgeleiden in de organisatie, mede in vergelijking tot naastliggende opleidingen.

- De tweede, middelste, laag betreft de positie van de hoger opgeleiden binnen de organisatie, in het bijzonder die van het HBO. Hier gaat het om de algemene rollen die hoger opgeleiden binnen de organisatie vervullen ten aanzien van markt, technologie en organisatie en hoe deze zich voor de hbo-opgeleide verhouden ten opzichte van de woopgeleide. 
- De derde, buitenste, laag betreft de economische omgeving van de organisatie en zijn positie daarin. Het gaat hier om de voor de desbetreffende organisatie relevante positie en ontwikkelingen hierin ten aanzien van markten, technologie en organisatie.

Hoewel in het pilot-project van de Hogeschool INHOLLAND - dat plaatsvindt in het kader van de accreditatie van een aantal opleidingen - deze drie verschillende niveaus aan bod komen, zal het accent komen te liggen op de binnenste laag. Bij deze binnenste laag valt te denken aan:

- De functionele rol die de desbetreffende hbo-afgestudeerde in algemene zin (zie middelste laag) maar ook in specifieke zin (de concrete functie) in de organisatie vervult.

- De beoordeling van de prestaties van de betrokkene in deze functie en het verwachte loopbaanperspectief in termen van verandering van functionele positie en toename van verantwoordelijkheden.

- Overwegingen om juist een afgestudeerde van de desbetreffende hbo-opleiding aan te trekken en de persoonlijke factoren die hierbij een rol speelden.

- De sterke en zwakke punten van de desbetreffende opleiding voor de vervulling van de functionele positie van de afgestudeerde in de organisatie, de verhouding hiervan met naastliggende hbo (en/of wo)-opleidingen, wenselijke veranderingen in de opleiding. Dit alles zo veel mogelijk losgemaakt van de persoonlijke invulling van de betrokken afgestudeerde. Inschatting van de mogelijke individuele afwijking in positieve dan wel negatieve zin op de bedoelde punten.

- De persoonlijke criteria die een rol hebben gespeeld om juist de desbetreffende hboafgestudeerde aan te trekken.

Bij de middelste laag kan worden gedacht aan het aantal aanwezige academici en hbo'ers, hun specifieke functionele rollen (zowel qua soort als daarin geleverde prestaties, en perspectief op langere termijn), en de voor hun inpassing in de functie en voor hun latere loopbaan te maken aanpassingskosten (qua aard en omvang).

Tenslotte, bij de buitenste laag kan worden gedacht aan het vergaren van informatie over: 1) voortgebrachte goederen en/of diensten, 2) marktontwikkeling, marktturbulentie en concurrentiepositie, 3) van belang zijnde technologieën, gebruikte technieken en hun vernieuwing, alsmede kennisbronnen hiervoor (inkoop, eigen R\&D, direct aanwezige kennisnetwerken met andere bedrijven en met onderwijsinstellingen), en 4) ondernemingsgrootte, ontwikkeling hiervan, managementlagen, functionele differentiatie (zijn de functies leiding, staf, ontwikkeling en uitvoering gescheiden of geïntegreerd?).

Uiteraard kunnen niet alle aspecten met betrekking tot de drie lagen van het onderzoek aan bod komen in de werkgeversvragenlijst. Het accent zal komen te liggen op het oordeel van de werkgever over de opleiding, de betekenis van de opleiding voor het innovatief vermogen van de organisatie, en de rol van zowel het initieel onderwijs als de werkgever bij het (verder) ontwikkelen van competenties. De werkgeversvragenlijst moet in ieder geval een consistente visie weerspiegelen op de vraag welke aspecten een opleiding relevant maken 
voor de kenniseconomie en wat het hieruit voortvloeiende afwegingkader voor werkgevers is voor het aantrekken van afgestudeerden van een bepaalde hogere opleiding.

\subsection{Werkgeversvragenlijst}

Zoals eerder is aangegeven, kunnen in dit werkveldonderzoek drie lagen worden onderscheiden:

- de relatieve positie van een organisatie met betrekking tot technologische, organisatorische en marktontwikkelingen;

- de rol van hoger opgeleiden bij technologische, organisatorische en marktontwikkelingen, en het leidinggeven hieraan binnen een organisatie;

- de eisen die worden gesteld ten aanzien van de afgestudeerden van een specifieke opleiding, en de positie van de opleiding t.o.v. andere opleidingen.

De in de appendix opgenomen vragenlijst, die gebruikt is in het pilot-werkveldonderzoek voor de Hogeschool INHOLLAND, bevat een aantal parameters over elk van deze drie lagen:

- laag 1: vraag 3, 4, 5 en 6;

- laag 2: vraag 2, 7 en 8;

- laag 3: vraag 9, 10, 11 en 12 .

Om overtollige uitleg bij de vragen te voorkomen, worden in de vragenlijst vooraf vier begrippen geïntroduceerd: de werknemer (de oud-student), de referentiefunctie (zijn of haar functie), de referentieopleiding (de door hem of haar gevolgde hbo-opleiding) en de organisatie (de organisatie waar de leidinggevende en de oud-student werkzaam zijn). In het vervolg van de vragenlijst worden deze begrippen telkens vetgedrukt, om de respondent er aan te herinneren dat het hier gaat om de in de toelichting gedefinieerde begrippen.

Toelichting op de vragen

\section{Vraag 1:}

De vragen over de leidinggevende zelf zijn voor een deel uit beleefdheid gesteld (het is niet erg netjes om helemaal geen belangstelling te tonen), maar kunnen van belang zijn voor de interpretatie van de resultaten. Vooral van belang is hoe lang men in dienst is geweest: hoe langer in dienst, hoe meer zal men over het bedrijf weten.

De vragen over de werknemer hebben voor een deel het doel om de aandacht van de leidinggevende te focussen: om welk persoon/functie gaat het hier? De werkzaamheden van de werknemer (en eventueel ook van de leidinggevende) zouden wellicht nader kunnen worden gecodeerd (los van de codering van beroep). De tijd dat de werknemer reeds in dienst is, kan worden gebruikt om te bepalen of het nog steeds om dezelfde werkgever gaat als in de vragenlijst HBO-Monitor is genoemd. 
Vraag 2:

Deze vraag is nodig omdat de branche als zodanig niet persé indicatief hoeft te zijn voor het werk dat men doet (bijvoorbeeld technische dienst binnen een universiteit).

Vraag 3:

Deze vraag is de eerste van een serie $(3 \mathrm{t} / \mathrm{m} 5)$ die tezamen met de bedrijfskenmerken uit de schoolverlatersdata (branche, organisatiegrootte en geografische locatie) het soort organisatie in kaart probeert te brengen. Vraag 3 gaat in op markt waarop de organisatie actief is. Hoofdgedachte bij deze vraag is dat een organisatie die op de internationale markt opereert (bijvoorbeeld een producent van batterijen voor GSM's) wezenlijk anders is dan een organisatie die sterk op de lokale markt actief is (bijvoorbeeld een badkamerinstallatiebedrijf).

\section{Vraag 4:}

Deze vraag gaat na in hoeverre de organisatie bloot staat aan concurrentie op de markt waarop zij actief is. De achterliggende gedachte bij deze vraag is dat naarmate er meer sprake is van concurrentie, de organisatie sterker genoopt is om innovaties door te voeren en bijgevolg om bijvoorbeeld meer bijscholingsactiviteiten te ontplooien.

\section{Vraag 5:}

Met behulp van deze vraag wordt gepoogd de door Michael Porter (1980, 1985) onderscheiden vier concurrentiestrategieën in kaart te brengen, te weten: 1) Cost Leadership, 2) Differentiation, 3) Focus "low costs", en 4) Focus "differentiation". Deze vier mogelijke strategieën worden aan de hand van twee dimensies in kaart gebracht, namelijk de soort markt waarop gedoeld wordt (breed of een bepaald segment) en het concurrentievoordeel (lage kosten of differentiatie). Dit gebeurt aan de hand van vijf stellingen waarmee respondenten op een 5-puntschaal kunnen aangeven in hoeverre ze het ermee eens zijn. Aangezien een deel van de vragenlijsten bij de publieke sector terecht zal komen, is de categorie 'niet van toepassing' toegevoegd.

\section{Vraag 6:}

Deze vraag brengt de veranderingen in kaart waarmee de organisatie wordt geconfronteerd. De literatuur en ook eerder ROA-onderzoek laat zien dat die veranderingen ruwweg op vier terreinen kunnen plaats vinden. Er wordt daarom gevraagd naar 1) veranderingen op het gebied van technologie/informatisering, 2) veranderingen van organisatorische aard, 3) veranderingen op het gebied van concurrentie en markten, en 4) veranderingen in de producten/diensten die de organisatie levert. Voor deze veranderingen wordt met behulp van een 5-puntsschaal gevraagd in hoeverre ze op de organisatie van toepassing zijn. 
Vraag 7:

Deze vraag poogt zicht te krijgen op de vier economische effecten van kennis die door Cörvers (1999) worden onderscheiden: het researcheffect (bewerkstelligen van technologische en organisatorische innovaties), het diffusie-effect (verspreiding van innovaties), het allocatie-effect (efficiënter en effectiever organiseren van het productieproces) en het arbeidseffect (efficiëntere functie-uitoefening). Deze vier effecten zijn op te vatten als instrumentele doelstellingen van organisaties. Door hierover informatie te verzamelen ontstaat een beeld over de mate waarin flexibiliteit en dynamiek een rol spelen binnen organisaties.

De vier economische effecten van kennis worden aan de hand van zes instrumenten in kaart gebracht. Vraag 7a kijkt in hoeverre de zes genoemde instrumenten van belang zijn voor de organisatie. Vraag 7b werpt licht op wat de afgestudeerde (en impliciet daarmee afgestudeerden van de betreffende opleiding) voor de organisatie betekent. Om de vragenlijst voor zowel de afgestudeerde als de respondent (de leidinggevende) acceptabel en zo min mogelijk afschrikkend te maken is er gekozen voor een positieve vraagstelling (“...goede bijdrage”, met een 5-puntsschaal van geheel oneens tot geheel eens. Dit om te voorkomen dat de vraag te zeer gezien wordt als een rapportcijfer voor de afgestudeerde.

Het verschil tussen het belang voor de organisatie en de bijdrage van de afgestudeerde geeft een indicatie van mogelijke discrepanties in de bijdrage van afgestudeerden aan de instrumentele doelstellingen van organisaties.

\section{Vraag 8:}

Deze vraag geeft een beeld van kennisontwikkeling en het kennismanagementbeleid van de organisatie. De vragen hebben daarmee ook implicaties voor employability van werknemers. Er wordt zowel aandacht besteed aan de aard van de kennis, de manieren waarop ze aangeleerd kan worden en de mate waarin ze aan veroudering onderhevig is. Item 5 is enigszins experimenteel ingevoegd. Daarmee wordt geprobeerd te meten in hoeverre de benodigde kennis voor de functie redelijk stabiel is, of juist nogal dynamisch van aard.

Vraag 9 en 10:

Deze vragen zijn bedoeld om een beeld te geven van de mate waarin de referentieopleiding met andere opleidingen concurreert voor de referentiefunctie, en welke andere opleidingen dat eventueel zijn. Voor een deel geven ze ook een beeld van het selectiebeleid van de organisatie met betrekking tot de referentiefunctie.

Vraag 11 en 12:

Vraag 11a geeft een beeld van het nadere selectiebeleid van de organisatie met betrekking tot de referentiefunctie, en vraag 11b van het doorstroombeleid. Vraag 12 geeft aan in hoeverre de genoemde aspecten een rol hebben gespeeld specifiek bij het aantrekken van 
de werknemer. Deze informatie kan in het aggregaat worden gebruikt om de sterke punten van de betreffende opleiding in kaart te brengen: wat zijn de belangrijkste redenen van werkgevers om afgestudeerden van deze opleiding aan te nemen. Aspecten 1, 2, 3, 4, en 6 komen globaal overeen met de vijf Dublin-descriptoren: 1) kennis \& inzicht, 2) toepassen van kennis \& inzicht, 3) oordeelsvorming, 4) communicatie, en 5) leervaardigheden.

\subsection{Gebruiksdoelen}

De gegevens uit het werkveldonderzoek zijn onder meer bruikbaar (als aanvulling op en in combinatie met gegevens uit de HBO-Monitor) voor accreditatiedoeleinden. De hierboven genoemde Dublin-descriptoren zijn richtinggevend hierbij. Toegespitst op hbo(-bachelors)opleidingen zijn vijf descriptoren van belang:

1. Kennis en inzicht

2. Toepassen van kennis en inzicht

3. Oordeelsvorming

4. Communicatie

5. Leervaardigheden

Het werkveldonderzoek levert met name voor wat betreft de tweede descriptor een waardevolle aanvulling op de individuele gegevens uit de HBO-Monitor. Volgens deze descriptor dient de hbo-bachelor in staat te zijn om zijn kennis en inzicht op dusdanige wijze toe te passen, dat dit een professionele benadering van zijn werkzaamheden of beroep laat zien. Bovendien zou de beginnende beroepsbeoefenaar moeten beschikken over competenties voor het opstellen en verdiepen van argumentaties en voor het oplossen van problemen op het vakgebied. Door de functionele rol van de afgestudeerde in de werkorganisatie te schetsen, waarbij in het bijzonder de sterke en zwakke punten van de opleiding worden belicht, kan een evenwichtig beeld worden verkregen van de mate waarin afgestudeerden van verschillende opleidingen voldoen aan de verwachtingen van het werkveld in termen van professioneel functioneren. Ook met betrekking tot de andere vier descriptoren kan het werkveldonderzoek een nuttig aanvulling zijn op de HBO-Monitor.

Behalve voor accreditatiedoeleinden kunnen de gegevens uit het werkveldonderzoek onder meer worden gebruikt voor:

- het bewerkstelligen van een betere afstemming van de opleiding op verwachtingen van het werkveld;

- beroeps- en loopbaanvoorlichting;

- $\quad$ het verkrijgen van inzicht in concurrerende opleidingen en daarmee te zijner tijd in de relatieve positie van opleidingen in het bama-tijdperk;

- het verkrijgen van inzicht in de aard van de behoefte aan bijscholing binnen organisaties;

- het verkrijgen van inzicht in relevante ontwikkelingen met betrekking tot markten, technologie en organisatie, die van belang kunnen zijn voor het bijstellen/ontwerpen van curricula. 


\section{Opzet van het pilot-project}

\subsection{Onderzoekspopulatie en wijze van dataverzameling}

\section{Onderzoekspopulatie}

De onderzoekspopulatie bij het onderzoek onder werkgevers van INHOLLANDafgestudeerden bestaat uit de huidige direct leidinggevenden van oud-studenten van 11 opleidingen van de hogeschool, die aan de HBO-Monitor 2001 of HBO-Monitor 2002 hebben deelgenomen. ${ }^{3}$ Tabel 4.1 geeft een overzicht van de opleidingen, de locaties van de hogeschool en de aantallen respondenten bij de HBO-Monitor 2001 (afstudeerjaargang 1999/2000) en HBO-Monitor 2002 (afstudeerjaargang 2000/2001), die in de pilot zijn betrokken.

Tabel 4.1

Aantal respondenten in HBO-Monitor $2001+2002$

Opleiding

Locaties

Alkmaar Diemen Haarlem Rotterdam Totaal

\begin{tabular}{|c|c|c|c|c|c|}
\hline Bedrijfskundige informatica & 27 & 29 & & & 56 \\
\hline Chemische laboratoriumopleiding/Chemie & 32 & & & & 32 \\
\hline Medische laboratoriumopleiding/Biologie en medisch & & & & & \\
\hline laboratoriumonderzoek & 24 & & & & 24 \\
\hline Bouwkunde & & & 59 & & 59 \\
\hline Civiele techniek & 42 & & 19 & & 61 \\
\hline Communicatie & & 175 & & 163 & 338 \\
\hline Facilitaire dienstverlening/Facility Management & & 56 & & & 56 \\
\hline $\begin{array}{l}\text { Medisch beeldvormende en radiotherapeutische } \\
\text { technieken }\end{array}$ & & & 37 & & 37 \\
\hline Mondhygiëne & & 43 & & & 43 \\
\hline Personeel en arbeid & & & 117 & 19 & 136 \\
\hline Sociaal pedagogische hulpverlening & & & 32 & 64 & 96 \\
\hline Totaal & 125 & 303 & 264 & 246 & 938 \\
\hline
\end{tabular}

\section{Werkwijze}

De werkgevers zijn benaderd via de oud-studenten. Daartoe is aan de oud-studenten de volgende stukken gezonden:

1. een pakketje, bestemd voor hun direct leidinggevende;

2. een aanbiedingsbrief, waarin de oud-studenten werden verzocht om het pakketje door te geven aan hun direct leidinggevende;

3. een antwoordkaart (port betaald) waarop de oud-studenten konden aangeven of zij bereid waren om aan het onderzoek mee te werken, en indien 'nee', waarom niet.

3. Oud-studenten die zelfs na 2 rappels niet hebben gerespondeerd op meting 2001 dan wel meting 2002 van de HBO-Monitor, zullen hoogstwaarschijnlijk ook niet bereid zijn om aan deze pilot mee te werken. 
Het pakketje voor de direct leidinggevende bestond uit een portvrije retourenvelop met daarin een aanbiedingsbrief en de vragenlijst. De vragenlijst was voorzien van een administratief codenummer, dat gekoppeld is aan het administratief codenummer van de oud-student.

Gepoogd is om de bereidwilligheid van de oud-studenten om de vragenlijst door te geven aan hun direct leidinggevende te verhogen door in de aanbiedingsbrief een appèl te doen op hun verbondenheid met hun vroegere hogeschool. In de aanbiedingsbrief is ook gewezen op het internetadres waar zij de terugrapportage kunnen vinden.

Ter verhoging van de bereidwilligheid van de direct leidinggevenden om aan het onderzoek mee te werken, is in de aanbiedingsbrief voor de leidinggevende een appèl gedaan op de werkrelatie met de desbetreffende oud-student. In de brief is ook gewezen op de geplande terugrapportage via de website van het ROA. Daarnaast is de mogelijkheid aangeboden van een terugrapportage via e-mail.

\subsection{Verslag van de dataverzameling}

\section{Antwoordkaarten}

Zoals eerder is vermeld, is aan de oud-studenten een brief gezonden, vergezeld van een pakketje voor hun direct leidinggevende. Bijgevoegd was tevens een antwoordkaart (port betaald) waarop de oud-studenten konden aangeven of zij bereid waren om aan het onderzoek mee te werken, en indien 'nee', waarom niet. Via de antwoordkaarten is getracht te achterhalen waar de 'bottleneck' voor medewerking aan het onderzoek zich zou voordoen: bij de oud-studenten of bij de werkgevers.

Op 25 augustus 2003 is de dataverzameling gestart. Van de 938 aangeschreven oudstudenten zijn uiteindelijk 128 antwoordkaarten terug ontvangen, ofwel 14\%. Dit lage percentage vormt een eerste indicatie dat de 'bottleneck' voor medewerking aan het onderzoek zich bij de oud-studenten heeft voorgedaan. Een tweede indicatie hiervoor vormen de resultaten in tabel 4.2. Deze laten namelijk zien dat van de 128 oud-studenten die het antwoordkaartje wel hebben geretourneerd, maar liefst 70 oud-studenten (ofwel $55 \%$ ) aangaven dat zij de vragenlijst niet hebben doorgegeven aan hun werkgever. Op de redenen die zij hiervoor aangaven, wordt later teruggekomen.

Dat de 'bottleneck' voor medewerking aan het onderzoek zich bij de oud-studenten heeft voorgedaan, blijkt tot slot uit het feit dat van de 53 oud-studenten die de vragenlijst aan hun werkgever hebben doorgegeven, 38 corresponderende werkgeversvragenlijsten zijn ontvangen (ofwel, maar liefst 72\%). Dit wel erg hoge percentage werkgevers die responderen, kan duiden op selectiviteit. Waarschijnlijk zijn het vooral de oud-studenten die een goede band hebben met hun directe leidinggevende, die de vragenlijst hebben doorgegeven. 
Antwoordkaart van oud-student
Vragenlijst ontvangen van werkgever
Vragenlijst aan werkgever doorgegeven

53

Vragenlijst nog niet aan werkgever doorgegeven, maar wel van plan

Vragenlijst niet aan werkgever doorgegeven

Totaal terug ontvangen antwoordkaarten
38

$2^{*}$

* Oud-studenten die als zelfstandige werkten.

Redenen om de vragenlijst niet door te geven

Kolom 2 in tabel 4.3 geeft een overzicht van de redenen die op de antwoordkaartjes zijn genoemd om de vragenlijst niet door te geven aan de directe leidinggevende. Deze redenen duiden er op dat het onderzoek voor velen niet relevant was (vanwege het niet verrichten van werk of het niet hebben van een leidinggevende), of als niet relevant werd gezien (omdat het werk niet aansluit op de opleiding). Een op de zeven oud-studenten weigerde mee te werken omdat men niet geïnteresseerd was in het onderzoek. Overigens heeft niemand expliciet aangegeven dat het onderzoek als bedreigend werd gezien.

Indicaties voor non-respons, verkregen op andere wijze dan via de antwoordkaartjes (kolom 3 in tabel 4.3), wijzen op een verouderd adressenbestand als mogelijke belangrijke oorzaak voor de lage respons op de antwoordkaartjes.

Tabel 4.3

Reden om de vragenlijst niet door te geven aan de werkgever (n)

Reden genoemd op antwoordkaart
Anderszins vernomen reden*
Voltijds studerend

Werkzaam als zelfstandige

Geen interesse in (dit soort) onderzoek

Verouderd adres

Werk sluit niet aan op opleiding

Werkloos/zwangerschapsverlof/sabbatical

Wereldreis/vakantie

Leidinggevende niet Nederlandstalig

Diverse andere redenen ${ }^{* *}$

Geen reden ingevuld

Totaal

$\begin{array}{rr}24 & 2 \\ 12 & 1 \\ 10 & 2 \\ & 13\end{array}$

6

62

4

2

6

1

71
2

2

1

1

22

* Via telefoon/e-mail vernomen, of onbestelbaar retour ontvangen.

** Bijvoorbeeld: oud zeer over de opleiding, zelf de hoogste leidinggevende, pas nieuwe baan.

Het hoge aandeel van voltijd studerenden duidt op selectiviteit in de respons op de antwoordkaarten. Op de selectiviteit in de uiteindelijke respons zal later worden ingegaan. 


\section{Belronde}

Van de aangeschreven oud-studenten hebben, zoals vermeld, er 128 een antwoordkaart teruggestuurd. Over 22 oud-studenten is anderszins iets vernomen. In totaal is dus van (of over) 150 van de 938 aangeschreven oud-studenten (ofwel 16\%) iets vernomen. Dit betekent dat over maar liefst $84 \%$ helemaal niets is vernomen. Naar aanleiding van de tegenvallende respons is door DESAN een belronde gehouden bij een aselecte steekproef van 20 oud-studenten waarvan nog geen enkele reactie was vernomen. De bedoeling was om een indicatie te verkrijgen van de redenen waarom deze oud-studenten helemaal niets van zich hebben laten horen. Na herhaald bellen konden uiteindelijk 16 (ouders van) oudstudenten worden bereikt.

Tabel 4.4

Bevindingen uit de belronde m.b.t. de adressen ( $n$ )

$\begin{array}{lr}\text { Vragenlijst binnengekomen op actueel adres } & 7 \\ \text { Vragenlijst binnengekomen op verouderd adres, wel doorgegeven aan oud-student } & 5 \\ \text { Vragenlijst binnengekomen op verouderd adres, niet doorgegeven aan oud-student } & 4 \\ \text { Totaal } & 16\end{array}$

Uit de belronde kwam als eerste naar voren dat bij 9 van de 16 oud-studenten de mailing op het ouderlijk adres ${ }^{4}$ was binnengekomen, terwijl deze oud-studenten niet langer thuis woonachtig waren. Kortom, bij meer dan de helft van deze 16 aselect gekozen oudstudenten bleek het adres niet actueel te zijn. Uit de belronde is overigens gebleken dat 5 van de 9 ouders bij wie de oud-studenten niet langer woonachtig waren, de vragenlijst hebben doorgegeven aan hun zoon of dochter. Per saldo heeft de vragenlijst 4 van de 16, ofwel $25 \%$ van de oud-studenten uit de belronde niet bereikt.

Navraag bij de 12 oud-studenten uit de belronde bij wie de vragenlijst wel (direct of indirect) terecht is gekomen, leerde het volgende:

- 4 oud-studenten waren om verschillende redenen niet bereid om aan het onderzoek mee te werken;

- 6 oud-studenten waren er om verschillende redenen nog niet aan toe gekomen om de vragenlijst door te geven aan hun directe leidinggevende, maar waren alsnog bereid om mee te werken;

- voor 2 oud-studenten was het onderzoek, vanwege studie of het niet verrichten van werk, niet relevant.

\section{Rappel}

Vanwege te tegenvallende respons, is besloten tot een tweede mailing. Deze is op 6 oktober 2003 verzonden. Op die dag bedroeg het aantal terug ontvangen ingevulde werkgeversvragenlijsten 52 . Uitgezonderd van de tweede mailing waren degenen die op de eerste

4. Waarvan bij 1 oud-student het adres van een studentenhuis, waar hij of zij had gewoond. 
mailing (al dan niet positief) hadden gereageerd en degenen waarvan de eerste mailing onbestelbaar retour was ontvangen. Op 15 november (bij de aanvang van de analyse en verslaglegging van de resultaten) bedroeg het aantal terug ontvangen ingevulde werkgeversvragenlijsten in totaal 84 , ofwel $9 \%$ van het totaal aantal aangeschreven oudstudenten. Over de resultaten uit deze 84 werkgeversvragenlijsten is in een separaat verslag ten behoeve van Hogeschool INHOLLAND gerapporteerd.

Overigens zijn na 15 november nog 4 ingevulde werkgeversvragenlijsten binnengekomen. Daarmee bedraagt de uiteindelijke respons 88 terug ontvangen ingevulde werkgeversvragenlijsten van de 938 benaderde oud-studenten, ofwel 9,4\% (stand op 15 december 2003).

\subsection{Respons en representativiteit}

Respons naar cohort en opleiding

Tabel 4.5

Respons naar opleidingsrichting

Respons (\%) Respons (n)

$\begin{array}{lrr}\text { Bouwkunde } & 12 & 7 \\ \text { Civiele techniek } & 12 & 7 \\ \text { Chemische laboratoriumopleiding/Chemie } & 16 & 5 \\ \text { Medische laboratoriumopleiding/Biologie en medisch laboratoriumonderzoek } & 17 & 4 \\ \text { Bedrijfskundige informatica } & 4 & 2 \\ \text { Communicatie } & 5 & 18 \\ \text { Facilitaire dienstverlening/Facility Management } & 5 & 3 \\ \text { Medisch beeldvormende en radiotherapeutische technieken } & 5 & 2 \\ \text { Mondhygiëne } & 23 & 10 \\ \text { Personeel en arbeid } & 10 & 14 \\ \text { Sociaal pedagogische hulpverlening } & 13 & 84 \\ \text { Totaal } & & 9\end{array}$

De respons bij afstudeerjaargang 1999/2000 bedraagt 7\% en bij afstudeergang 2000/2001 $10 \%$. Dat de respons bij het oudere cohort lager is, kan een indicatie vormen voor veroudering van de adressenbestanden en 'verbleking' van de binding met de 'oude' hogescholen. ${ }^{5}$ Het ontbreken van een systematisch alumnibeleid bij deze vroegere hogescholen (thans gefuseerd tot Hogeschool INHOLLAND) draagt wellicht hiertoe bij. Hierop zal later in deze paragraaf aan de hand van een pilot project bij de Universiteit Maastricht worden teruggekomen.

Tabel 4.5 toont dat de respons soms sterk verschilt tussen de opleidingen, variërend van $4 \%$ voor de opleiding Bedrijfskundige informatica tot $23 \%$ voor de opleiding Mondhygiëne. Als gevolg van deze verschillen in respons, laat tabel 4.6 zien dat het werkveld van de

5. Hierbij zij opgemerkt dat de hogeschool INHOLLAND nog niet bestond toen de aangeschreven oudstudenten afstudeerden. Zij zullen derhalve nauwelijks of geen binding hebben met INHOLLAND. 
opleidingen bedrijfskundige informatica, facilitaire dienstverlening, medisch beeldvormende $\&$ radiotherapeutische technieken en vooral communicatie ondervertegenwoordigd is in de respons. Het werkveld van de opleiding mondhygiëne is duidelijk oververtegenwoordigd.

Tabel 4.6

Representativiteit naar opleidingsrichting (\%)

Aandeel in totale populatie
Aandeel in respons

Bouwkunde

Civiele techniek

Chemische laboratoriumopleiding/Chemie

$\begin{array}{rr}6 & 8 \\ 7 & 8 \\ 3 & 6 \\ & \\ 3 & 5 \\ 6 & 2 \\ 36 & 21 \\ 6 & 4 \\ 4 & 2 \\ 5 & 12 \\ 15 & 17 \\ 10 & 14 \\ & \\ 100 & 100 \\ 938 & 84\end{array}$

Medische laboratoriumopleiding/Biologie en medisch

laboratoriumonderzoek

Bedrijfskundige informatica

Communicatie

Facilitaire dienstverlening/Facility Management

Medisch beeldvormende en radiotherapeutische technieken

Mondhygiëne

Personeel en arbeid

Sociaal pedagogische hulpverlening

938

8

5

21

4

2

12

14

Totaal

Totaal $n$

\section{Representativiteit naar aansluiting opleiding-werk}

De respons op het werkveldonderzoek is groter bij oud-studenten die werk hebben dat aansluit op hun opleidingsrichting, dan bij oud-studenten wier werk niet aansluit op hun opleidingsrichting (tabel 4.7).

Tabel 4.7

Representativiteit naar aansluiting opleiding-werk* $(\%)$

Non-respondenten

76

72

Respondenten

Werk sluit aan op opleidingsniveau

Werk sluit aan op opleidingsrichting **

* Het betreft het werk circa anderhalf jaar na afstuderen.

** Verschil tussen respons en non-respons significant op 1\%-niveau.

\section{Pilot bij de Universiteit Maastricht}

Een systematisch alumnibeleid is weliswaar bevorderlijk voor de actualiteit van een adressenbestand van oud-studenten, maar vormt desondanks geen garantie voor een hogere respons bij dit soort onderzoek. Dit is gebleken bij een gecombineerde afgestudeerden-werkgevers enquête onder oud-studenten die 5,5 jaar geleden zijn afgestudeerd aan de Faculteit der Economische Wetenschappen en Bedrijfskunde (FdEWB) van de Universiteit Maastricht (UM), waar wel sprake is van een systematisch alumnibeleid. 
De respons onder de werkgevers bedroeg daar na 1 mailing slechts 4,6\%. Opgemerkt moet worden dat de pilot bij de FdEW een groter beslag heeft gelegd op de bereidwilligheid van oud-studenten om mee te werken dan de pilot bij Hogeschool INHOLLAND. Immers de oudstudenten van de FdEWB moesten niet alleen een werkgeversvragenlijst doorgeven aan hun directe leidinggevende, maar ook zelf een loopbaanvragenlijst invullen (afgestudeerden van de andere faculteiten van de UM hoefden geen werkgeversvragenlijst door te geven aan hun directe leidinggevende).

Het lijkt overigens dat deze gecombineerde afgestudeerden-werkgevers enquête ten koste is gegaan van de respons onder de oud-studenten zelf. Aanwijzingen hiervoor zijn af te leiden uit de cijfers in tabel 4.8. Deze laten immers zien dat de respons onder oud-studenten van de FdEWB in de meting zonder werkgeversbenadering (de meting na 10,5 jaar) slechts $2 \%$-punt lager is dan onder oud-studenten van de andere faculteiten van de UM. In de gecombineerde afgestudeerden-werkgevers meting onder oud-studenten van de FdEWB (de meting na 5,5 jaar) ligt hun respons maar liefst 9\%-punt lager dan de respons van de oud-studenten van de andere faculteiten, die niet hebben deelgenomen aan een pilot onder werkgevers.

Tabel 4.8

Respons (na 1 mailing) op de eind 2003 gehouden loopbaanmetingen onder oud-studenten van de UM (\%)

FdEWB

28

(1)

Andere faculteiten
Loopbaanmeting na 5,5 jaar

Loopbaanmeting na 10,5 jaar
25

30

\footnotetext{
* Gecombineerde afgestudeerden-werkgevers enquête.
}

\section{Conclusies}

Bij onderwijsinstellingen blijkt een grote behoefte te bestaan aan informatie over de rol van de werkgever bij de transitie van school naar werk en het oordeel van de werkgever over de opleiding. Met het oog hierop heeft het ROA in 2003 twee pilots uitgevoerd: een pilot bij Hogeschool INHOLLAND en een pilot bij de Universiteit Maastricht. De pilot bij Hogeschool INHOLLAND was gericht op afgestudeerden van een elftal opleidingen van de cohorten 1999/2000 en 2000/2001. De pilot bij de Universiteit Maastricht was gericht op de afgestudeerden van de economische faculteit van het cohort 1996-1997. In beide werkgeversonderzoeken is er voor gekozen de afgestudeerde te vragen een schriftelijke werkgeversvragenlijst aan zijn of haar directe leidinggevende door te geven. Hiermee werd beoogd een representatieve steekproef onder werkgevers te creëren. Bovendien zou deze opzet het mogelijk maken de informatie afkomstig van de afgestudeerde en van zijn of haar werkgever aan elkaar te koppelen.

Helaas hebben beide pilots niet het gewenste resultaat opgeleverd. De respons in de pilot bij Hogeschool INHOLLAND is met uiteindelijk 88 ingevulde werkgeversvragenlijsten (respons $9,4 \%$ ) teleurstellend laag gebleken. De respons in de pilot bij de Universiteit Maastricht is 
met 4,6\% (hetgeen neerkomt op 14 ingevulde werkgeversvragenlijsten) zelfs nog beduidend lager. Een brede waaier van factoren blijkt een rol te spelen bij deze teleurstellende respons. Geen interesse is slechts één van die factoren. Een verouderd adres een andere factor. Daarnaast blijkt uit de pilot voor INHOLLAND dat de respons afneemt, naarmate men langer is afgestudeerd. Deels heeft dit te maken met verouderde adressen, maar wellicht ook met de afnemende binding met de opleiding. Ten slotte is de combinatie van een uitgebreide vragenlijst voor de afgestudeerde zelf en het verzoek de werkgeverslijst door te geven aan de direct leidinggevende, zoals in de pilot bij de Universiteit Maastricht het geval was, mogelijk iets teveel gevraagd. Een aanwijzing hiervoor is dat in de pilot bij de Universiteit Maastricht ook de respons onder de afgestudeerden zelf negatief lijkt te worden beïnvloed.

De belangrijkste conclusie uit de pilot bij zowel de Hogeschool INHOLLAND als de Universiteit Maastricht moet luiden dat een benadering van het werkveld via de oudstudenten tot een te lage en niet representatieve respons leidt. De gekozen onderzoeksopzet is waarschijnlijk mede debet aan de teleurstellende respons. Gezien de toegevoegde waarde voor het onderzoek naar de transitie van school naar werk en de belangrijke inzichten die het raadplegen van werkgevers kan opleveren in het kader van curriculumevaluatie en kwaliteitszorg, blijft werkgeversonderzoek wenselijk. Wellicht een betere optie, dan de bij deze pilots gehanteerde opzet, is om in de enquête onder afgestudeerden te vragen naar de naam en het adres van de werkorganisatie en later, los van de afgestudeerden-enquête, de werkgevers rechtstreeks te benaderen.

Zoals eerder is gezegd, zijn echter ook een verouderd adressenbestand en wellicht ook een afnemende binding met de opleiding debet aan de lage respons. Het up-to-date houden van adressenbestanden in het kader van een actief alumni-beleid is dan ook van cruciaal belang voor het welslagen van onderzoek waarbij oud-studenten zijn betrokken.

\section{Literatuur}

Cörvers, J.G.F. (1999), The Impact of Human Capital on International Competitiveness and Trade Performance of Manufacturing Sectors, Dissertation.

Porter, M.E. (1980), Competitive Strategy: Techniques for Analysing Industries and Competitors, The Free Press, New York.

Porter, M.E. (1985), Competitive advantage: Creating and sustaining superior performance, The Free Press, New York. 
Appendix: Vragenlijst Werkveldonderzoek Hogeschool INHOLLAND 

Met zwarte of blauwe pen invullen

In deze vragenlijst wordt de werknemer van wie u deze enquête heeft gekregen kortheidshalve de werknemer genoemd, haar of zijn functie de referentiefunctie, de door haar of hem gevolgde HBO-opleiding de referentieopleiding, en de organisatie waar u beiden werkzaam bent de organisatie.

1. Geef in het schema informatie over uw eigen functie en de functie van de werknemer

- naam functie:

- belangrijkste werkzaamheden:

- hoe lang in dienst (ongeveer):

2. Wat is de belangrijkste functie van uw afdeling/eenheid binnen de organisatie? (één antwoord)

\section{uw functie}

jaren

maanden

jaren

maanden

3. Markt waarop de organisatie vooral actief is (één antwoord)

1 primair proces van de organisatie

2 ondersteunend op financieel-economisch gebied

3 ondersteunend op personeelsgebied

4 ondersteunend op intern technisch gebied

5 ondersteunend op strategisch gebied

6 verkoop of marketing

7 research \& development

8 management

9 anders, namelijk:

4. Ongeveer hoeveel andere organisaties zijn op deze markt actief?

\begin{tabular}{|l|l|}
\hline 1 & lokaal \\
\hline 2 & regionaal \\
\hline 3 & landelijk \\
\hline 4 & internationaal \\
\hline
\end{tabular}

1 geen andere organisaties (mijn organisatie is de enige aanbieder)

21 of 2 andere organisaties

3 tot 5 andere organisaties

46 tot 10 andere organisaties

5 meer dan 10 andere organisaties

5. In hoeverre bent $u$ het eens met de volgende stellingen:

1. De organisatie concurreert vooral door de kosten (en de prijzen) zo laag mogelijk te houden.

2. De organisatie concurreert vooral door producten of diensten te ontwikkelen die anders zijn dan het aanbod van andere organisaties.

3. De organisatie richt zich op een specifiek en klein deel van de markt.

4. De organisatie streeft naar een zo groot mogelijk marktaandeel.

5. De organisatie is actief op een markt waar sprake is van veel concurrentie.

6. In hoeverre zijn de volgende veranderingen op de organisatie van toepassing?

\begin{tabular}{|c|c|c|c|c|c|}
\hline \multicolumn{2}{|c|}{$\begin{array}{l}\text { volledig mee } \\
\text { oneens }\end{array}$} & $\longleftrightarrow$ & \multicolumn{2}{|c|}{$\begin{array}{r}\text { volledig mee } \\
\text { eens }\end{array}$} & \multirow{2}{*}{$\begin{array}{c}\begin{array}{c}\text { niet van } \\
\text { toepassing }\end{array} \\
6\end{array}$} \\
\hline 1 & \begin{tabular}{|l}
2 \\
\end{tabular} & \begin{tabular}{|l}
3 \\
\end{tabular} & 4 & 5 & \\
\hline \begin{tabular}{|l|}
1 \\
\end{tabular} & \begin{tabular}{|l}
2 \\
\end{tabular} & 3 & 4 & 5 & \begin{tabular}{|l}
6 \\
\end{tabular} \\
\hline \begin{tabular}{|l|}
1 \\
\end{tabular} & $\begin{array}{l}2 \\
\end{array}$ & \begin{tabular}{|l}
3 \\
\end{tabular} & 4 & $\begin{array}{l}5 \\
\end{array}$ & \begin{tabular}{|l}
6 \\
\end{tabular} \\
\hline \begin{tabular}{|l|}
1 \\
\end{tabular} & \begin{tabular}{|l}
2 \\
\end{tabular} & \begin{tabular}{|l}
3 \\
\end{tabular} & \begin{tabular}{|l}
4 \\
\end{tabular} & $\begin{array}{l}5 \\
\end{array}$ & \begin{tabular}{|l|}
6 \\
\end{tabular} \\
\hline \begin{tabular}{|l|}
1 \\
\end{tabular} & \begin{tabular}{|l}
2 \\
\end{tabular} & \begin{tabular}{|l}
3 \\
\end{tabular} & 4 & \begin{tabular}{|l|}
5 \\
\end{tabular} & \begin{tabular}{|l}
6 \\
\end{tabular} \\
\hline
\end{tabular}

1. Veranderingen op het gebied van technologie en informatisering

2. Organisatorische veranderingen

3. Veranderingen op het gebied van concurrentie op afzetmarkt(en)

4. Veranderingen in de producten of diensten die de organisatie levert

niet

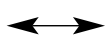

in sterke mate

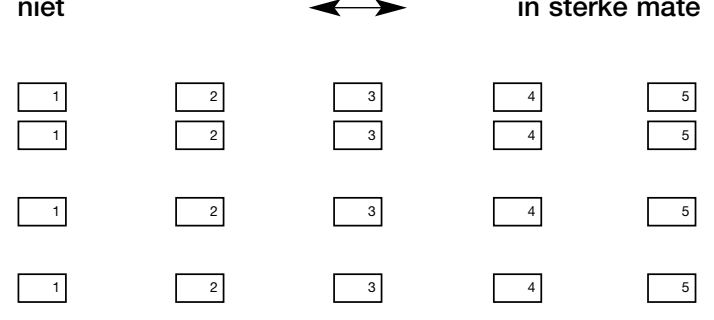


7. Kunt $\mathrm{u}$ aangeven in hoeverre:

a. de hieronder genoemde instrumenten voor de organisatie van belang zijn

b. de werknemer hieraan bijdraagt

1. grote directe inzetbaarheid

2. grote mate van flexibiliteit

3. ontwikkeling van nieuwe technieken en werkmethoden

4. efficiënt omgaan met machines, middelen en mensen

5. verbetering van de productiviteit

6. snel aanpassen aan en kunnen omgaan met nieuwe technieken en werkmethoden

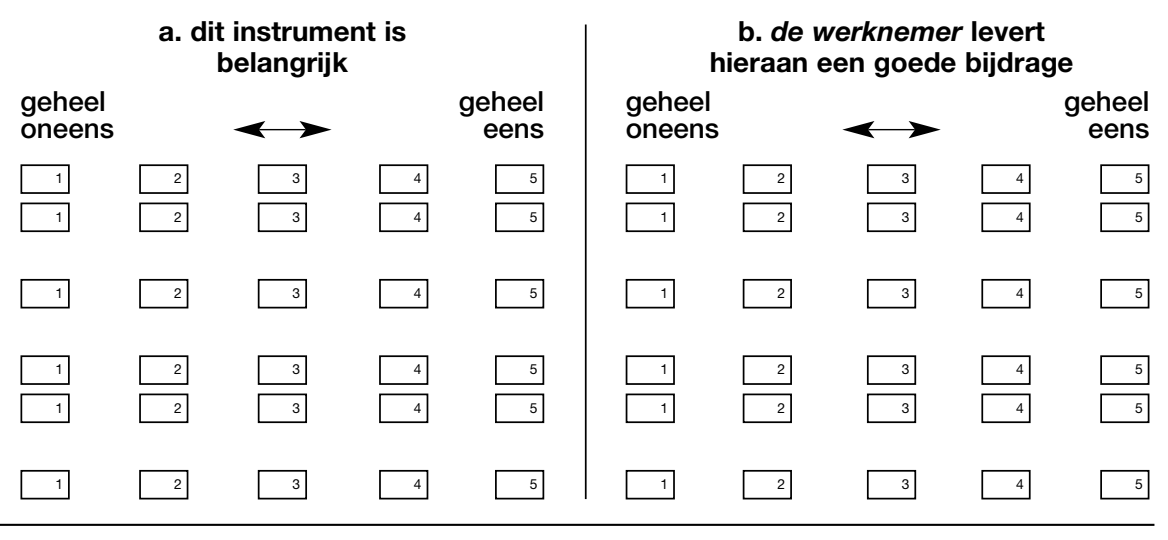

8. Is de kennis die vereist is voor

de referentiefunctie:

1. specifiek voor de organisatie?

2. bruikbaar in andere organisaties?

3. intern ontwikkeld binnen de organisatie?

4. aan veroudering onderhevig?

5. sterk wisselend door het jaar?

6. via de HBO-opleiding aan te leren?

7. via bedrijfsopleidingen aan te leren?

8. door te werken aan te leren?

9. In hoeverre is in de organisatie waar u werkzaam bent de referentieopleiding nodig voor de referentiefunctie?

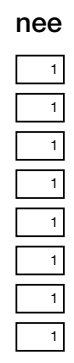

ja, enigszins

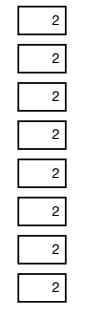

$\mathrm{ja}$, in sterke mate

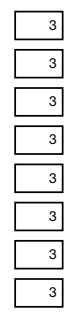

1 referentieopleiding is strikt vereist

$\rightarrow$ ga naar vraag 11

2 referentieopleiding is niet strikt nodig, wel geprefereerd

3 andere opleiding is beter

opleiding maakt niet zoveel uit

$\rightarrow$ ga naar vraag 11

10. Noem maximaal drie andere opleidingen die ook geschikt zijn voor de referentiefunctie. (geef zowel schooltype als opleidingsrichting aan, bijv. HBO Bedrijfseconomie, WO Psychologie)
1. schooltype:
opleidingsrichting:
2. schooltype:
opleidingsrichting:
3. schooltype:
opleidingsrichting:

11. In hoeverre zijn onderstaande aspecten van belang bij:
a. de selectie van werknemers voor de referentiefunctie
b. de doorstroom naar hogere functies
1. beheersing vakkennis
2. toepassing vakkennis
3. vermogen tot afgewogen oordeelsvorming
4. communicatieve vaardigheden
5. managementvaardigheden
6. leervaardigheden
7. beheersing vreemde talen
8. relevante werkervaring
9. extra genoten opleidingen/cursussen
10. kwaliteit onderwijsinstelling
11. anders, namelijk:

12. Noem uit bovenstaande lijst $(1 \mathrm{t} / \mathrm{m} 11)$ de drie aspecten die het zwaarst hebben gewogen bij het aantrekken van de werknemer

a. bij selectie
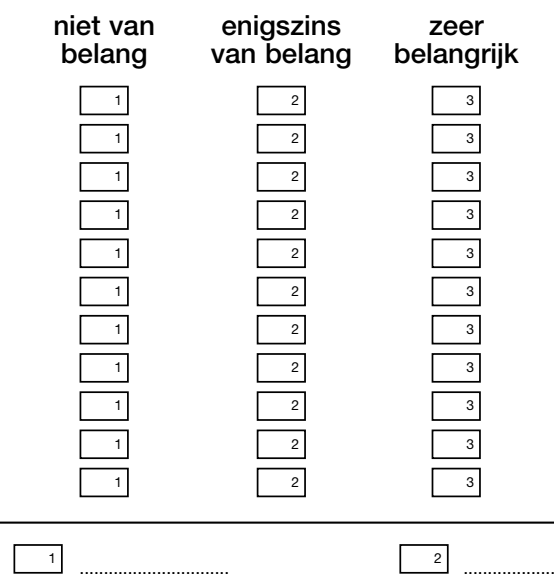

weet niet (niet betrokken bij selectieproces) b. bij doorstroom

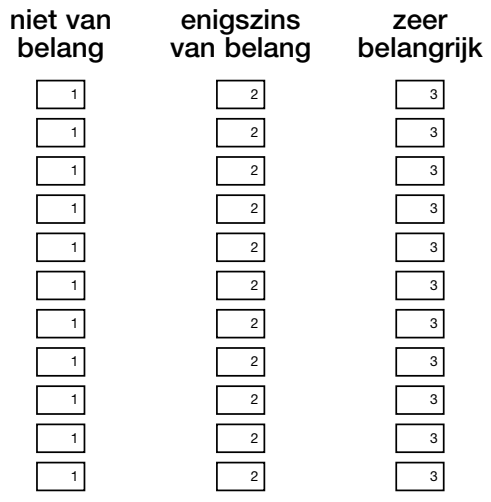

Stelt u prijs op elektronische toezending van de resultaten van dit onderzoek, vul dan uw e-mail adres in:

@...

(uw e-mail adres zal alleen voor het toezenden van de resultaten worden gebruikt. Hierna zal uw e-mail adres uit ons bestand worden verwijderd)

\section{Opmerkingen/suggesties}

